\title{
1: $222319711-222339996$
}

National Cancer Institute

\section{Source}

National Cancer Institute. 1:222319711-222339996. NCI Thesaurus. Code C42194.

Physical location of EPHX1_Gene 